\title{
DISCURSO DEL Dr. HORACIO H. URTEAGA
}

Abierta la actuación por el Rector de la Dniversidad, doctor Alfredo Solf y Muro, hizo uso de la palabra, el Decana de la Facultad. de Letras y Presidente del Instituto Cultural Peruano Argentino, doctor Horacio H. Urteaga, quien se expresó en los siguientes términos:

Proyectado por el Instituto Peruano-Argentino este homenaje al genial educador Domingo Faustino Sarmiento, en el aniversario de su muerte, la Facultad de Filosofía, Historia y Letras de esta vieja Casa de San Marcos, se ha asociado al recuerdo de esta memorable efemérides con el más austero fervor.

No hay todavía suficiente perspectiva histórica para juzgar al genial argentino; recién comienza América a incorporarse al movimiento universal, y los originales índices de su cultura recién se esbozan en el vasto panorama del proceso humano. Pero no está lejano el día en que la gran figura del autor de "Facundo" adquiera su relieve máximo y aparezea en la historia con la talla indo-latina y el sello de uno de los más grandes educadores y forjadores de pueblos libres.

La vida del grande hombre es ya una enseñanza, como que fué vida de apóstol, con su aeeión perseverante en educar y en instruir. Enseñó quer la vida noble elai vida vroyechosa, la verdadera vida plena, debe ser como pensaba Guyau: una educación incesante y que hay que aprender, desde hablar hasta morir.

Fué Sarmiento un tipo representativo en la más grande acepción; encarnando las fuerzas telúricas y asi mismo las aspiracioues de su pueblo, que lleno de vigor al emanciparse, quizo conocer, quizo comprender y dominar la ciencia humana, tesoro común que debe ser aprovechado por todos los hombres. Quizo más, hacer a su pueblo digno de la libertad conquistada, enseñándole a ser libre.

Sarmiento es el fruto sazonado de la conjunción del medio y de la raza y el más grande representativo del espíritu de una época. Las fuerzas teuléricas y las potencias espirituales han forjado el alma de este argentino genial que se alza en el escenario agitado de su patria, para predecirle con su ejemplo y con su acción, cómo se puede defender la libertad y cómo se puede asegurar la nobleza del porvenir.

Pedagogo de acción, iluminado por su ideal, fuerte y recio; en ocasiones extravagante o iluminado como es el genio; es, como dice uno de sus biógrafos: "hijo de la roca y del desierto, como aque- 
lla ave simbólica", de altísimos destinos comunes en América. Pero batallador y combativo, fué, sin embargo, un gran corazón; un filántropo insaciable de amor y de felicidad para sus hermanos de raza y de destino.

No fué como quería Marco Aurelio, un emperador filósofo; pero fué un maestro, guía de su pueblo. Desde su sitial de gobernante enseñó a todos, directores y dirigidos a mandar, a conducir, sentando esta doctrina que será eterna: Que lo único sólido y perperdurable en la acción del que manda es la elevación del espíritu nacional, por la obra lenta del educador, y que la mejor lección de democracia y liberalismo está cimentada en la educación e instrucción del pueblo.

La Facultad de Letras, la más alta cátedra de educación nacional, evoca el espíritu de Domingo Faustino Sarmiento en esta fecha memorable para proclamar, que el genial maestro argentino, ha comprometido, por sus enseñanzas y su ejemplo, la gratitud de América.

El doctor Pedro Dulanto, encargado del discurso de orden, os va a hacer conocer en todas sus facetas la grande y noble figura del maestro.

\section{Biblioteca de Letras "Jorge Puccinelli Converso"}

